спорта к предстоящей профессиональной деятельности имеет теоретическое и практическое значение для научного обоснования и реализации аксиологических подходов в сфере высшего профессионального образования.

$$
\text { **** }
$$

1. Гущина Н.В. Формирование профессиональной компетентности будущего тренера по спортивной аэробике в процессе обучения дисциплине «Педагогическое физкльтурно- спортивное совершенствование»: автореф. дис. ... канд. пед наук / Н.В.Гущина - Чебоксары, 2009. - 23с.

2. Мясищев, В. Н. Психология отношений /В.Н. Мясищев. М.: Изд-во «ИПП»; Воронеж: Изд-во НПО МОДЭК, 1995.- $350 \mathrm{c.}$

3. Николаев, Ю.М. Теория физической культуры: функциональный, ценностный, деятельностный и результативный аспекты: учебное пособие/СПбГАФК им. П.Ф. Лесгафта. / Ю.М. Николаев. - СПб.: Изд-во СПбГАФК, 2000. - 80 с.

4. Оссовский, В. Л. Ценности профессиональной деятельности: автореф. дисс. ... д-ра филос. Наук /В.Л. Оссовский. - К., 1986.- 47 с.

5. Сластёнин, В. А. Введение в педагогическую аксиологию: учеб. пособие для студ. высш. пед. учеб. Заведений / В.А. Сластенин, Г.И. Чижакова. М.: Издательский центр «Академия», 2008. - 192 с.

\title{
Затоненко А.А. \\ Основные принципы, обеспечивающие эффективность реализации методики обучения иноязычному общению младших школьников на основе интеграции дисциплин «Иностранный язык» и «Физическая культура»
}

Курский государственный университет (Россия, Курск)

doi: $10.18411 / \mathrm{lj}-31-08-2017-22$

idsp: 000001:lj-31-08-2017-22

\section{Аннотация}

Статья посвящена проблеме обучения иноязычному общению младших школьников на основе интеграции дисциплин «Иностранный язык» и «Физическая культура». Автор статьи детально останавливаются на номенклатуре ведущих принципов, обеспечивающих эффективность процесса обучения иноязычному общению младших школьников на основе интеграции указанных дисциплин. В качестве ведущих принципов в предлагаемой системе обучения автор выделяет следующие: принщип целостности развивающейся личности, принцип коммуникативности, принщип системности, принщип личностно-ролевого общения, принции коллективного взаимодействия.

Ключевые слова: обучение иноязычному общению, младшие школьники, интеграция, иностранный язык, физическая культура

\section{Abstract}

The article is devoted to the problem of teaching young learners foreign language communication on the basis of integration of the disciplines "Foreign Language" and "Physical Culture". The author singles out main principles of the communicative foreign language learning process on the integration of the given subjects. The main principles singled out by the author are: the principle of developing personality integrity, the principle of communicative interaction, the principle of systematic character, the principle of role communication, the principle of collective interaction.

Key words: Foreign Language Teaching, Young Learners, Integration, Foreign Language, Physical Culture

Важнейшей составляющей теоретического блока модели является система принципов, взаимодействие которых способствует формированию коммуникативных 
умений и стратегий общения у младших школьников в процессе интеграции дисциплин «Иностранный язык» и «Физическая культура».

К ведущим принципам в предлагаемой модели представляется целесообразным отнести следующие: принщй целостности развивающейся личности, принщии коммуникативности, принщип системности, принции личностно-ролевого общения, принщип коллективного взаимодействия.

Принщип иелостности развивающейся личности подразумевает целостное развитие личности обучающихся, формирование целостного мировоззрения и миропонимания в процессе интегративного изучения дисциплин «Иностранный язык» и «Физическая культура». Процесс обучения иноязычному общению младших школьников на интегративной основе предполагает комплексное формирование всех личностных качеств обучающихся. Личность следует развивать в неразрывном единстве всех ее составляющих: интеллектуальной, физической, духовной, психологической, эмоциональной.

Принцип коммуникативности, основан на учете закономерностей реального общения в процессе обучения иноязычному общению младших школьников. В процессе обучения иноязычному общению реализуются все характеристики повседневного общения, такие как: целенаправленность, мотивированность, информативность, эмоциональность. Коммуникация на иностранном языке является каналом обучения, развития, воспитания и познания для младших школьников в ходе осуществления спортивно-оздоровительной деятельности. «Создать процесс обучения, как модель процесса общения, означает смоделировать основные, принципиально важные, сущностные параметры общения, к которым относятся: личностный характер коммуникативной деятельности субъекта общения, взаимопонимание и взаимодействие речевых партнеров, ситуации как формы функционирования общения, содержательная основа процесса общения, система речевых средств, эвритичность (новизна) общения» $[4$, c. 78$]$.

Принции системности, который предусматривает системное усвоение содержания иноязычного образования в процессе реализации всех его аспектов: учебного, воспитательного, развивающего и познавательного, а также всеми аспектами языка: интонационным, грамматическим, лексическим и стилистическим. В процессе реализации обучения иноязычному общению младших школьников на основе интеграции дисциплин «Иностранный язык» и «Физическая Культура» происходит овладение иностранным языком, как целостной системой, включающей в себя неразрывное единство интеллектуальной, эмоциональной и физической составляющей. [1, c. 61].

Принцип системности подразумевает последовательное осуществление всех этапов обучения иноязычному общению на основе интеграции дисциплин «Иностранный язык» и «Физическая Культура» в ходе реализации спортивнооздоровительной деятельности. К данным этапам можно отнести следующие:

a) получение теоретических знаний, необходимых для эффективного овладения умениями и стратегиями общения (соотнесения функции и формы языкового явления);

б) овладение коммуникативными средствами общения на основе использования опор;

в) овладение коммуникативными средствами общения без использования опор;

г) применение коммуникативных средств, в постоянно меняющихся ситуациях общения.

Принции личностно-ролевого общения. Личностное и ролевое общения пересекаются и соединяются в процессе интеграции дисциплин «Иностранный язык» и «Физическая культура». В ходе спортивно оздоровительной деятельности младшие школьники выполняют различные роли для осуществления группового и 
коллективного взаимодействия: роль лидера, роль подчиненного, роль координатора, роль консультанта, роль делового партнера [3, с. 117].

Учебная деятельность осуществляется в процессе ролевой игры. На каждом занятии дети получают роли-маски (отрицательные, положительные), способствующие тому или иному их поведению в различных ситуациях ролевого общения. Роли-маски могут также помочь младшим школьникам побороть чувство неловкости, стеснения, преодолеть боязнь сделать ошибку, а учителю - создать нужную благоприятную творческую атмосферу на занятиях.

Принции коллективного взаимодействия предполагает единство действий всех участников коммуникации для достижения общей цели. Обучающиеся осуществляют интеллектуальную и физическую деятельность для достижения наиболее эффективного результата в заданных условиях общения. Дети выполняют упражнения с элементами сотрудничества и соперничества, вызывающие положительную мотивацию. В иноязычном образовании важное место отводится заданиям, при выполнении которых каждый ребенок из группы должен внести вклад в коллективное дело, построенное на интеграции коммуникативной и физической деятельности. Данные задания предполагают сотрудничество и взаимопомощь детей в команде [2, с. 133].

Все указанные принципы, представляют собой неразрывное единство в процессе решения учебных, развивающих и воспитательных задач в ходе иноязычного образования младших школьников на основе интеграции дисциплин «Иностранный язык» и «Физическая культура.

$$
* * *
$$

1. Затоненко А.А. Обучение младших школьников иноязычному общению на основе интеграции дисциплин «Иностранный язык» и «Физическая культура» // Среднее Профессиональное Образование: Ежемесячный теоретический и научно-методический журнал: № 10 / Отв. ред. М.Ю. Гастева - Москва: Российская академия образования и Союз директоров ссузов России, 2015. - С. 59-62.

2. Китайгородская Г.А. Методические основы интенсивного обучения иностранным языкам. - М.: Изд-во МГУ, 1986.

3. Ковальчук М.А. Дискуссия как средство обучения иноязычному общению. - М.: Высшая школа, 2008.

4. Пассов Е.И. Основы коммуникативной методики обучения иноязычному общению. - М.: Русский язык, 1989.

\section{Колбасина Л.В., Нуржанова Р.М. Интеграция международного опыта в систему повышения квалификации Филиал АО «НЦПК «Өрлеу» ИПК ПР по Костанайской области»}

doi: $10.18411 / \mathrm{lj}-31-08-2017-23$

idsp: 000001:lj-31-08-2017-23

\section{Аннотация}

В статье рассматриваются вопросы интеграции международного опыта в систему повышения квалификации Казахстана. Казахстан постепенно входит в мировое экономическое сообщество. Система образования республики претерпевает изменения. Которые непосредственно касаются системы повышения квалификации педагогических работников.

В связи с тем, что сегодня отчетливо просматривается процесс демократизации международных отношений и утверждение партнерства как основной формы сотрудничества, изучение зарубежного опыта модернизации систем повышения квалификации является достаточно актуальной задачей в настоящее время.

Ключевые слова: интеграция, повышение квалификации, модернизация, оптимизация, реформирование и трансформация. 